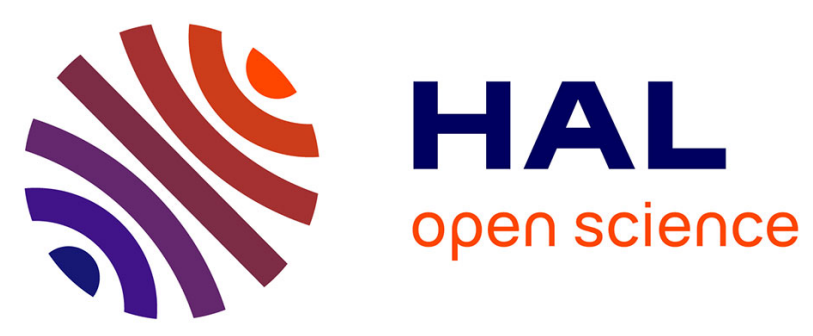

\title{
Design of magnetic molecularly imprinted polymer nanoparticles for controlled release of doxorubicin under an alternative magnetic field in athermal conditions
}

\author{
N. Griffete, J. Fresnais, A. Espinosa, C. Wilhelm, A. Bée, C. Ménager
}

\section{- To cite this version:}

N. Griffete, J. Fresnais, A. Espinosa, C. Wilhelm, A. Bée, et al.. Design of magnetic molecularly imprinted polymer nanoparticles for controlled release of doxorubicin under an alternative magnetic field in athermal conditions. Nanoscale, 2015, 7 (45), pp.18891-18896. 10.1039/C5NR06133D . hal01229896

\section{HAL Id: hal-01229896 \\ https://hal.sorbonne-universite.fr/hal-01229896}

Submitted on 17 Nov 2015

HAL is a multi-disciplinary open access archive for the deposit and dissemination of scientific research documents, whether they are published or not. The documents may come from teaching and research institutions in France or abroad, or from public or private research centers.
L'archive ouverte pluridisciplinaire HAL, est destinée au dépôt et à la diffusion de documents scientifiques de niveau recherche, publiés ou non, émanant des établissements d'enseignement et de recherche français ou étrangers, des laboratoires publics ou privés. 


\title{
Journal Name
}

\section{COMMUNICATION}

\section{Design of Magnetic Molecularly Imprinted Polymer Nanoparticles for Controlled Release of Doxorubicin under Alternative Magnetic Field in Athermal Conditions.}

\author{
N. Griffete, ${ }^{a} *$ J. Fresnais, ${ }^{a}$ A. Espinosa, ${ }^{b}$ C. Wilhelm, ${ }^{b}$ A. Bée ${ }^{a}$ and C. Ménager ${ }^{a}$
}

\begin{abstract}
An innovative magnetic delivery nanomaterial for triggered cancer therapy showing active control over drug release by using alternative magnetic field is proposed. In vitro and in living cells release of doxorubicin (DOX) were investigated and showed a massive DOX release upon alternative magnetic field without temperature elevation of the medium.
\end{abstract}

During the last decade, nanotechnologies for anticancer drug delivery ${ }^{1}$ have been extensively explored, hoping to improve local efficacy and to reduce side effects of chemotherapy. In an ideal targeted drug delivery system, nanomaterials would be directed to the tumor tissue and selectively release therapeutic molecules.

Molecularly imprinted polymers ${ }^{2}$ (MIPs), which possess selective affinity and sustained release behavior toward specific biomolecules have found applications in biosensing ${ }^{3}$, drug delivery ${ }^{4}$, bioseparation ${ }^{5}$ as well as diagnostics and therapeutics ${ }^{6}$. The biomolecules served as templates during the polymerization of the functional monomer to get the MIP. The advantage in drug delivery of such a system is the possibility to regulate drug release by increasing the residence time of the therapeutic agent within the polymeric matrix, by means of either covalent or non-covalent interactions in specific binding sites. The release of the drug doesn't depend on the swelling degree of the polymer unlike strategy involving a polymer shell.

Magnetic nanoparticles have attracted considerable attention for magnetic targeting ${ }^{7}$ and magnetic hyperthermia applications ${ }^{8}$ owing to their ability to generate heat when exposed to an alternative magnetic field (AMF) without penetration depth limit. However, heat therapy with magnetic hyperthermia needs a high accumulation of nanoparticles to provide macroscopic therapeutic heating, quite unrealistic with systemic delivery. As a consequence, new strategies were recently envisaged to trigger drug delivery. ${ }^{9,10}$ Temperatureresponsive carriers like mesoporous silica NPs coated with a thermosensitive polymer ${ }^{11}$, polymersomes ${ }^{12}$, liposomes ${ }^{13}$ or microgels ${ }^{14}$ exhibit an increase of permeability above a defined transition temperature which induces subsequent release of the drugs. Another way to induce the drug delivery is to use hyperthermia to break bonds between magnetic nanoparticles and the drug ${ }^{15}$. That is the case of a recent study where ligands linked to magnetic nanoparticles took benefits from local heating of nanoparticle's surface to release a fluorophore on demand ${ }^{16}$. The weak interactions existing in supramolecular magnetic nanoparticles can also be broken under AMF like J. Cheon and co-workers proposed ${ }^{17}$. This approach is very interesting because it can be performed without macroscopic temperature elevation ${ }^{18}$.

In this study we propose to destabilize the weak interactions existing between the MIP and the drug to trigger the drug release in athermal conditions under AMF. We designed a new magnetic doxorubicin delivery system ( $\left.\mathrm{Fe}_{2} \mathrm{O}_{3} @ D O X-\mathrm{MIP}\right)$ by growing molecularly imprinted polymers from individual iron oxide nanoparticles surface via an acrylic acid monomer (AA) used as polymerization initiator anchored on the surface of $\mathrm{Fe}_{2} \mathrm{O}_{3}$ nanoparticles and doxorobucin as template ${ }^{19}$. The DOX release of such functional $\mathrm{Fe}_{2} \mathrm{O}_{3} @ D O X-$ MIP NPs was investigated in vitro and in living cells under AMF excitation. 


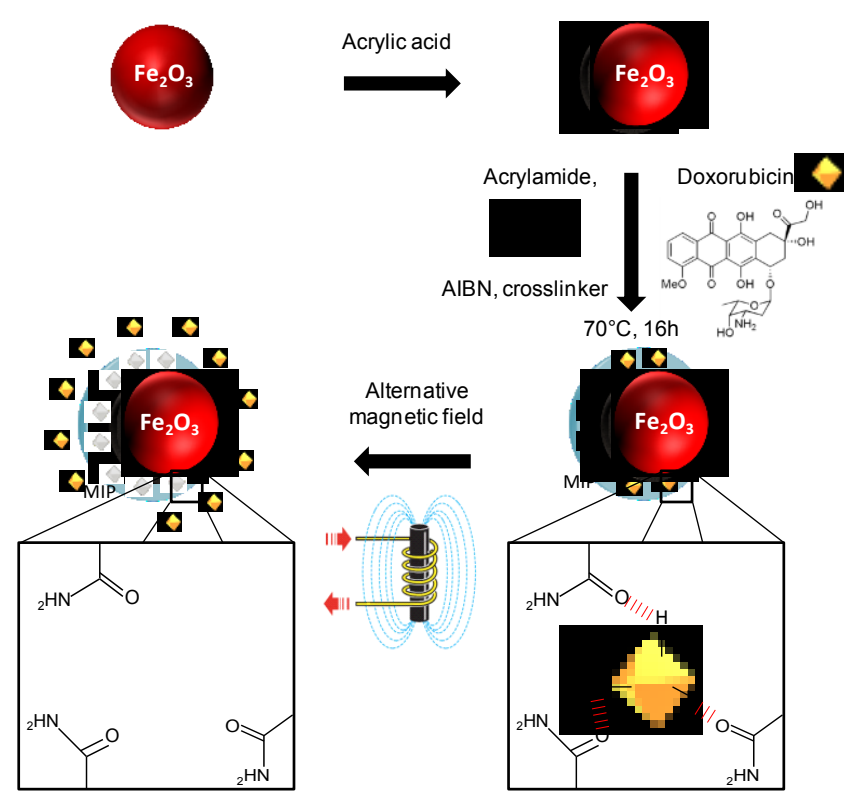

Scheme 1. Two-step synthesis of $\mathrm{Fe}_{2} \mathrm{O}_{3} @ D O X-M I P$ via a subsequent grafting of an acrylic acid compound and the growth of the polymer at $70^{\circ} \mathrm{C}$. AMF induces DOX release.

We prepared $\mathrm{Fe}_{2} \mathrm{O}_{3} @$ DOX-MIP NPs according to Scheme 1. The $\gamma-\mathrm{Fe}_{2} \mathrm{O}_{3} \mathrm{NPs}$ (maghemite) were first synthesized through a coprecipitation method, followed by a size sorting process through salt destabilization to get the biggest NPs which are more efficient for magnetic hyperthermia ${ }^{20}$.

TEM analysis shows particles with an average particle diameter $\left(\mathrm{d}_{0}\right)$ of $11 \mathrm{~nm}$ and a polydispersity $(\sigma)$ of 0.31 (Fig. $\mathrm{S} 1 \mathrm{a}, \mathrm{ESI}+$ ). To stabilize and functionalize the $\mathrm{Fe}_{2} \mathrm{O}_{3} \mathrm{NPs}$, an acrylic acid function was anchored by complexation with unsaturated iron ions at the nanoparticle surface. Then, the polymerization could proceed, mixing $\mathrm{Fe}_{2} \mathrm{O}_{3}$-AA nanoparticles with acrylamide as the functional monomer, ethylene glycoldimethacrylate (EGDMA) as the crosslinking agent, azo(bis)isobutyronitrile (AIBN) as the polymerization initiator and doxorubicin (DOX) as the template molecule in ethanol. The deoxygenated mixture was heated for $16 \mathrm{~h}$. The final product, consisting of nanoparticles coated by a molecularly imprinted polymer ( $\left.\mathrm{Fe}_{2} \mathrm{O}_{3} @ D O X-M I P\right)$, was dialyzed during 24 hours, washed several times by magnetic separation and finally dispersed in water. A reference non-imprinted polymer sample ( $\left.\mathrm{Fe}_{2} \mathrm{O}_{3} @ \mathrm{NIP}\right)$ was prepared using the same procedure, but without addition of the template (DOX molecules). It is noteworthy that the polymer layer for $\mathrm{Fe}_{2} \mathrm{O}_{3} @ D O X-M I P$ nanoparticles (Fig. S1b, ESI+) is too thin to appear on the TEM images, however no morphological change or aggregation is observed due to polymerization process.

The surface chemistry of the $\mathrm{Fe}_{2} \mathrm{O}_{3} @ D O X-M I P$ was assessed by Fourier transform infrared (FT-IR; Fig. S2, ESI + ). The Fe-O stretching peak at $\sim 586 \mathrm{~cm}^{-1}$ was observed for the two samples, indicating that the composition of $\mathrm{Fe}_{2} \mathrm{O}_{3}$ was not changed after polymer coating. The band observed for the $\mathrm{Fe}_{2} \mathrm{O}_{3}$ particles at $1385 \mathrm{~cm}^{-1}$, characteristic of the nitrate ion with $D_{3 h}$ symmetry $\left(v_{3}\right.$ mode $)$, is not visible after polymerization indicating the surface modification of the particles. The vibration band at $1728 \mathrm{~cm}^{-1}$ ( $\mathrm{C}=\mathrm{O}$ stretching) appears when magnetic nanoparticles were covered with MIP that contains a large number of $\mathrm{C}=\mathrm{O}$ groups in poly(acrylamide) units confirming the successful growth of polymer.

Thermogravimetric analysis (TGA) showed that the amount of MIP on $\mathrm{Fe}_{2} \mathrm{O}_{3} @$ DOX-MIP was about 70\% of the total particle weight, as determined from the significant mass change between 270 and $400^{\circ} \mathrm{C}$ owing to decomposition of MIP (Fig. S3, ESIt).

The $\mathrm{Fe}_{2} \mathrm{O}_{3}$ NPs were found to be covered with MIP after polymerization, as observed by the increase in size (from 31 to $57 \mathrm{~nm}$ ) using dynamic light scattering (DLS - Fig. S4, ESI+). DLS and zeta potential were measured for both $\mathrm{Fe}_{2} \mathrm{O}_{3}$ and $\mathrm{Fe}_{2} \mathrm{O}_{3} @ D O X-M I P$ NPs versus pH (Fig. S5a and S5b, ESI + ). The hydrodynamic diameter of $\mathrm{Fe}_{2} \mathrm{O}_{3} @ D O X-M I P$ particles is constant on the whole $\mathrm{pH}$ range according to their constant zeta potential $(-27 \mathrm{mV})$. As the poly(acrylamide) is non $\mathrm{pH}$ sensitive, this result is in agreement with the effective surface modification of the $\mathrm{Fe}_{2} \mathrm{O}_{3}$ NPs with the polymer coating.

Kinetic adsorption tests (Fig. S6, ESIt) onto the $\mathrm{Fe}_{2} \mathrm{O}_{3} @ D O X-M I P$ after DOX extraction (named $\mathrm{Fe}_{2} \mathrm{O}_{3} @ M I P$ ) and $\mathrm{Fe}_{2} \mathrm{O}_{3} @$ NIP were performed by measuring the adsorption of DOX at regular intervals from 5 to $120 \mathrm{~min}$ with the same initial concentration of DOX $(400 \mu \mathrm{M})$. The adsorption capacity (Q) of DOX onto the $\mathrm{Fe}_{2} \mathrm{O}_{3} @$ MIP has a fast adsorption profile within $20 \mathrm{~min}$, and then slows down gradually. After $20 \mathrm{~min}$, the adsorption has almost reached equilibrium. Compared to other surface imprinting technologies for DOX, the adsorption equilibrium time of the $\mathrm{Fe}_{2} \mathrm{O}_{3} @ M I P$ is similar ${ }^{18}$.

Isothermal adsorption experiments were carried out through varying the concentrations of DOX from 20 to $400 \mu \mathrm{M}$, with a mixing time of 3 hours (Fig. 1). It was shown that the $Q$ of DOX onto the $\mathrm{Fe}_{2} \mathrm{O}_{3} @ \mathrm{MIP}$ and $\mathrm{Fe}_{2} \mathrm{O}_{3} @ \mathrm{NIP}$ came to equilibrium over $200 \mu \mathrm{M}$. The results suggest that the recognition sites on the surface of the $\mathrm{Fe}_{2} \mathrm{O}_{3} @ M I P$ have better chemical and steric matching with the DOX than $\mathrm{Fe}_{2} \mathrm{O}_{3} @ N I P$ indicating a non-specific adsorption as the dominant effect and a lower binding affinity of $\mathrm{Fe}_{2} \mathrm{O}_{3} @ N I P$. The dissociation constant $K_{d}$ and the maximum binding number $\left(Q_{\max }\right)$ were calculated from the Scatchard equation for the prepared polymers (Fig. S7, ESI + ). The respective $K_{d}$ and $Q_{\max }$ values are $35.6 \mu \mathrm{mol} \mathrm{g}{ }^{-1}$ and 3.4 $\mu \mathrm{M}$ for the $\mathrm{Fe}_{2} \mathrm{O}_{3} @ \mathrm{DOX}-\mathrm{MIP}$ and 12.5 $\mu \mathrm{mol} \mathrm{g}{ }^{-1}$ and $100 \mu \mathrm{M}$ for the $\mathrm{Fe}_{2} \mathrm{O}_{3} @ D O X-N I P$. The difference in DOX binding affinity to the MIP and NIP clearly indicated the role of the imprinting process in the formation of specific binding sites. 


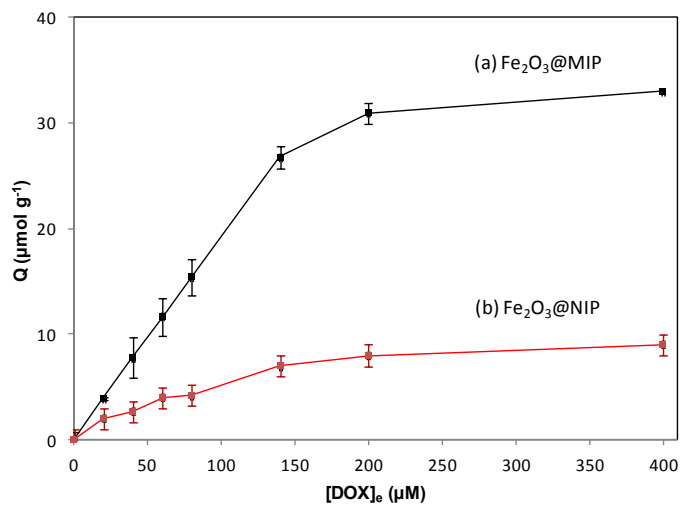

Fig. 1 Adsorption isotherms of $\mathrm{Fe}_{2} \mathrm{O}_{3} @ M I P$ (black) and $\mathrm{Fe}_{2} \mathrm{O}_{3} @ \mathrm{NIP}$ (red) toward Doxorubicin. Adsorption conditions: V $=5 \mathrm{~mL}, \mathrm{~m}_{\mathrm{MIPS}}=\mathrm{m}_{\mathrm{NIPS}}=20 \mathrm{mg}, \mathrm{T}=25^{\circ} \mathrm{C}, \mathrm{t}=3 \mathrm{~h}$.

$\mathrm{Fe}_{2} \mathrm{O}_{3}$ and $\mathrm{Fe}_{2} \mathrm{O}_{3} @ D O X-M I P$ NPs exhibit the same superparamagnetic behavior (Fig. S8, ESI+). More interestingly, the heating capacity also called the Specific Loss Power (SLP) of $\mathrm{Fe}_{2} \mathrm{O}_{3}$ and $\mathrm{Fe}_{2} \mathrm{O}_{3} @ D O X-M I P$ nanoparticles was measured at $335 \mathrm{kHz}$ and $9 \mathrm{mT}$ magnetic field. The uncoated NPs exhibit a SLP of $97 \mathrm{~W} . \mathrm{g}^{-1}$ in good agreement with theoretical and experimental expectations ${ }^{20}$. For the $\mathrm{Fe}_{2} \mathrm{O}_{3} @ D O X-M I P$, a SLP of $67 \mathrm{~W} . \mathrm{g}^{-1}$ is obtained with a temperature elevation rate of $0.33^{\circ} \mathrm{C} . \mathrm{s}^{-1}$. The SLP decrease may be explained by the appearance of some aggregates after polymerization as observed by DLS. However, the $\mathrm{Fe}_{2} \mathrm{O}_{3} @ D O X-M I P$ nanoparticles still have an interesting heating capacity if they are submitted to an alternative magnetic field.

To investigate the potential application of $\mathrm{Fe}_{2} \mathrm{O}_{3} @ D O X-M I P$ for drug delivery, in vitro DOX release studies were monitored in various conditions: in a water bath at human body temperature $\left(37^{\circ} \mathrm{C}\right.$ ) and under AMF (five AMF pulses of 2 minutes with a 30 s interval, $335 \mathrm{kHz}, 9 \mathrm{mT}$ ) at $37^{\circ} \mathrm{C}$ (Fig. $2 \mathrm{~A}$ and 2C). In order to determine the concentration of the DOX binds to the MIP, DOX molecules were extracted in a solvent (ethanol/acetic acid 9:1v/v). Extraction of the template is commonly done with a solvent that promotes the disruption of interactions between the polymer and the template while maintaining the structure of the three-dimensional polymer network $^{21}$. The supernatant was then collected by magnetic separation and analyzed by UV/Vis spectroscopy $1,2,3,4,6$ and $8 \mathrm{~h}$ after treatment; the materials released $12 \mu \mathrm{M}$ of DOX after $8 \mathrm{~h}$ (Fig. 2A). The amount of DOX extracted in acetic acid is used as reference for the calculation of the percentage of drug release (Fig. 2C). Then, samples $\left(\mathrm{Fe}_{2} \mathrm{O}_{3} @ D O X-M I P N P s, 2\right.$ $\mathrm{mL},[\mathrm{Fe}]=50 \mathrm{mM}$ ) were periodically placed under $A M F$ at the same time points. $\mathrm{Fe}_{2} \mathrm{O}_{3} @ D O X-M I P$ NPs submitted to AMF released $7.5 \mu \mathrm{M}$ of DOX after $8 \mathrm{~h}$ at $37^{\circ} \mathrm{C}$ (Figure $2 \mathrm{~A}$ ) whereas a sample left for $8 \mathrm{~h}$ at $37^{\circ} \mathrm{C}$ did not show any significant DOX release (15\%, Fig. 2B). Therefore the cumulative drug release reaches $60 \%$ under AMF. More interestingly for each time point, the drug release is significantly higher when the nanoparticles are submitted to an AMF. To evaluate the imprinting process role in the DOX release under $A M F$,
$\mathrm{Fe}_{2} \mathrm{O}_{3} @$ NIP NPs were incubated with DOX (C = 40 $\mu \mathrm{M}$, see supporting information) during $4 \mathrm{~h}$, dialyzed during $24 \mathrm{~h}$ and washed several times by magnetic separation and finally dispersed in water. The final product $\left(\mathrm{Fe}_{2} \mathrm{O}_{3} @ N I P-D O X, 2 \mathrm{~mL}\right.$, $[\mathrm{Fe}]=50 \mathrm{mM}, \mathrm{C}_{\mathrm{DOx}}=12 \mu \mathrm{M}$ ) was submitted to the same AMF excitation than the $\mathrm{Fe}_{2} \mathrm{O}_{3} @ D O X-M I P$ NPs. A sample left for $8 \mathrm{~h}$ at $37^{\circ} \mathrm{C}$ (Figures $2 \mathrm{~B}$ and $2 \mathrm{D}$ ) showed a high DOX concentration release $(9 \mu \mathrm{M}, 73 \%)$ and under $A M F$ the same material showed the complete release of the DOX after $8 \mathrm{~h}(11,8 \mu \mathrm{M}, 98 \%)$. A burst effect is observed when the DOX is just physically retained in the unprinted polymer shell around the particles. The slight effect observed upon AMF excitation is probably due to a more rapid diffusion of DOX molecules with the temperature elevation in the polymer matrix. These results taking together highlight the importance of the drug interactions with the polymer in the imprinting process to slow the release of the drug from the polymer network.
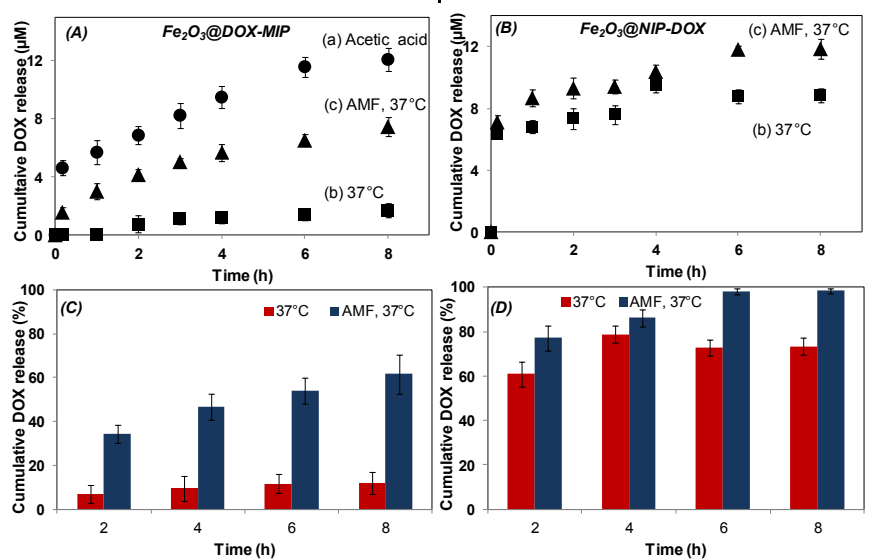

Fig. 2 Cumulative DOX release in $\mu \mathrm{mol} / \mathrm{L}$ and in percent versus time of $\mathrm{Fe}_{2} \mathrm{O}_{3} @ D O X-M I P(A)$ and $(B)$ and $\mathrm{Fe}_{2} \mathrm{O}_{3} @ N I P-D O X$ nanoparticles (C) and (D) ([Fe]=50 mM) (a) after acid treatment, (b) at $37^{\circ} \mathrm{C}$ without magnetic field and (c) under AMF $(335 \mathrm{kHz}, 9 \mathrm{mT})$.

To prove the universality of the imprinted method to other molecules, the same protocol has been carried out with fluorescein and rhodamine (Fig. S9, ESIt). Both imprinted particles exhibit a significant template release after AMF treatment compared to the sample without AMF (respectively 11.8 and $13.6 \mu \mathrm{M}$ versus 1.9 and $2.3 \mu \mathrm{M}$ ).

To show the crucial role of the magnetic core in the drug release process $\mathrm{Fe}_{2} \mathrm{O}_{3} \mathrm{NPs}$ were dissolved in $\mathrm{HCl}$ and after separation of the polymer from the acidic solution by ultracentrifugation, in vitro DOX release studies were monitored at $37^{\circ} \mathrm{C}$ under AMF. After $8 \mathrm{~h}$, the DOX release concentration is insignificant $\left(1.5 \mu \mathrm{M}\right.$, Fig. S10, ESI $\left.{ }^{\dagger}\right)$ confirming the importance of the magnetic core in the drug delivery system. As nanoparticles preferentially accumulate at the tumour site thanks to the Enhanced Permeability and Retention effect (EPR effect), using $\mathrm{Fe}_{2} \mathrm{O}_{3} @ D O X-M I P$ as drug delivery system could be useful in AMF-induced drug delivery applications. 
To evaluate the temperature effect on the drug-release profile, $\mathrm{Fe}_{2} \mathrm{O}_{3} @ D O X-M I P$ nanoparticles were heated at different temperatures (water bath) during 4 hours and supernatants were analyzed after magnetic separation (Fig. S11, ESI + ). The DOX concentration released after a bulk heating during $4 \mathrm{~h}$ at $37^{\circ} \mathrm{C}$ is of the order of $1.2 \mu \mathrm{M}$ which is three times lower than the amount of DOX released after 4 hours with AMF pulse at each time point $\left(5.6 \mu \mathrm{M}\right.$, Fig. $\left.1 \mathrm{~A}, \mathrm{ESI}{ }^{\dagger}\right)$ at the same temperature. The maximum of DOX release reached under AMF $(7.5 \mu \mathrm{M})$ is obtained for a temperature of $60^{\circ} \mathrm{C}$ whereas macroscopic temperature elevation measured during AMF experiments is only of $3^{\circ} \mathrm{C}$ (Fig. S12, ESI ${ }^{+}$). Therefore, we can conclude that the effect of AMF is due to a high temperature gradient from the nanoparticle surface, this gradient is restricted to the environment close to the periphery of the nanoparticle, thus leading to localized heating. The effect of this localized heating on the drug release may be explained by the destabilization of the weak interactions (hydrogen bonds) existing between the DOX and the MIP.

DOX release was then tested in cancer cells, with a view to future therapeutic application. $\mathrm{Fe}_{2} \mathrm{O}_{3} @ D O X-M I P$ nanoparticles were very efficiently captured by cancer cells (PC-3), with an iron load per cell of $10 \mathrm{pg}$, when incubation (2-hours) was performed at $[\mathrm{Fe}]=2 \mathrm{mM}$ (see also the uptake curve in Fig. $\mathrm{S} 13)$. This $[\mathrm{Fe}]=2 \mathrm{mM}$ concentration corresponds to a maximal DOX release on $\mu$ molar range (Fig. 2A). DOX was clearly associated to the tumor cells on confocal microscopy images (Fig. 3A), and cross-sectional images of the cells (Fig. 3B and Fig. S14, ESIt) demonstrate unambiguously its intracellular localization, sequestered inside intracellular endosome-like compartments. These $\mathrm{Fe}_{2} \mathrm{O}_{3} @ D O X-M I P$ nanoparticles internalization did not induce cancer cell death (Fig. 3C), demonstrating that when bonded to the MIP (and thus the nanoparticles), DOX is inactive. By contrast, after AMF application (at $700 \mathrm{kHz}, 25 \mathrm{mT}$ ), cancer cell viability was affected, with cell viability reduced to $60 \%$ after $1 \mathrm{~h} 30$ treatment (Fig. 3C). It is very important to emphasize here that this AMF-induced cancer cell death was achieved in athermal conditions. Indeed, during the AMF exposure, the cell medium was maintaining at a $37^{\circ} \mathrm{C}$ temperature (See Fig. S15, ESIt for the temperature monitoring during treatment). This is in agreement with the control experiment where cells loaded with the same amount of iron (10 pg per cell) but without DOX (incubation with $\mathrm{Fe}_{2} \mathrm{O}_{3} @$ citrate nanoparticles, with same magnetic core as $\mathrm{Fe}_{2} \mathrm{O}_{3} @ D O X-M I P$ nanoparticles) didn't suffer any mortality. Also worth noticing, the same levels of cell deaths were found when free DOX was incubated with the cancer cells for 2 hours at concentration in the range 0.5-2 $\mu \mathrm{M}$ (Fig. 3D), corresponding remarkably to the concentration which could be AMF released by the $\mathrm{Fe}_{2} \mathrm{O}_{3} @ D O X-M I P$ incubated with the cells. Taken together, these cellular experiments support the DOX release under AMF application evidenced in solution, and demonstrate the possibility of initiating a chemotherapeutic treatment via an athermal magnetic hyperthermia strategy. This remote magnetic activation of doxorubicin is particularly promising to limit the adverse effects of chemotherapy on bystander tissues.
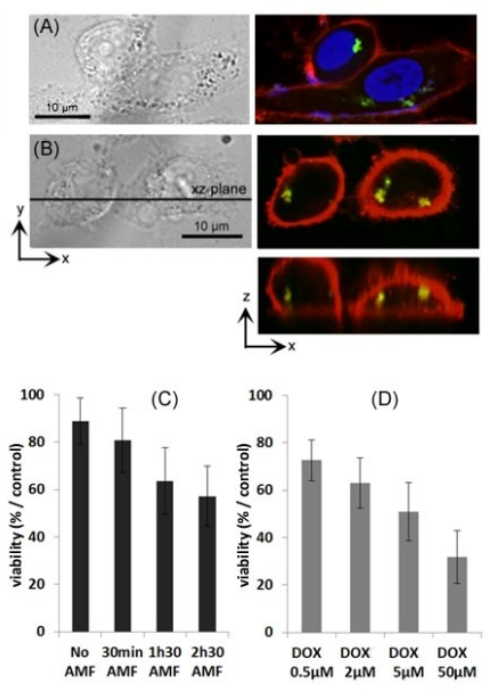

Fig. $3(\mathrm{~A}, \mathrm{~B})$ : Cancer cells (PC-3) internalization of the $\mathrm{Fe}_{2} \mathrm{O}_{3} @ D O X-M I P$ nanoparticles (2-hours incubation at $[\mathrm{Fe}]=2$ $\mathrm{mM}$ ). DOX is detected in the green channel (excitation at 488 $\mathrm{nm}$, emission at $561 \mathrm{~nm}$ ). Nuclei and cell membranes are stained by DAPI (A) in blue and $\operatorname{PKH} 26(A, B)$ in red, respectively. $Z$ reconstructions $(B)$ identify $D O X$ inside the cells. (C): Viability of cancer cells labelled with $\mathrm{Fe}_{2} \mathrm{O}_{3} @ D O X-M I P$ after exposure to the alternative magnetic field (AMF at 700 $\mathrm{kHz}, 25 \mathrm{mT}$ ) for $0 \mathrm{~min}$ (No AMF), 30min, 1h30, and $2 \mathrm{~h} 30$ compared to the control experiment (cancer cells labelled with $\mathrm{Fe}_{2} \mathrm{O}_{3}$ nanoparticles, at the same cellular iron dose, and exposed to the same conditions of AMF). The overall temperature during treatment was $37 ., 5{ }^{\circ} \mathrm{C}$ for both conditions. (D) Treatment of the cancer cells with free doxorubicin (DOX) incubated for 2 hours from 0.5 to $50 \mu \mathrm{M}$. Cell viability (normalized by control cells) was measured 24 hours after the incubation, in the exact same conditions as the ones used for $\mathrm{Fe}_{2} \mathrm{O}_{3} @ D O X-M I P$ after AMF treatment.

In summary, we reported the synthesis of an innovative magnetic delivery nanoplatform for triggered cancer therapy showing active control over drug release by using local effect of hyperthermia. Our material, wich combines the controlled drug release ability of non thermosensitive Molecularly Imprinted Polymers (MIP) with magnetic properties of iron oxide, allows the control release of doxorubicin. Upon AMF exposure, the hydrogen bonds between the MIP and the DOX are broken and the molecule is released without any significant heating of the medium. This strategy is efficient both in vitro and in living cells. These nanomaterials offer great promise for the doxorubicin release under magnetic field and moreover we think that this approach will be easily expanded to other polymers, targeting molecules or drugs. The use of Magnetic Molecularly Imprinted Polymers for drug delivery under alternative magnetic field (AMF) is a major advance in the development of multifunctional targeted drug delivery 
nanotechnologies and may become important theranostic tools in nanomedicine.

\section{Notes and references}

‡ We kindly acknowledge Delphine Talbot for the ATG characterization of the nanomaterials. We also thank Aude Michel and Sandra Casale for the TEM pictures.

1 S. Carregal-Romero, P. Guardia, X. Yu, R. Hartmann, T. Pellegrino and W. J. Parak Nanoscale, 2015, 7, 570; M Calero, L. Gutierrez, G. Salas, Y. Luengo, A. Lazaro, P. Acedo, M.P. Morales, R. Miranda, A. Villanueva, Nanomedicine: Nanotechnology, Biology, and Medicine, 2014, 10, 733; J. M. Rosenholm, C. Sahlgren and Mika Lindén, Nanoscale, 2010, 2, 1870; H. Kakwere, M.P. Leal, M.E. Materia, A. Curcio, P. Guardia, D. Niculaes, R. Marotta, A. Falqui and T Pellegrino, ACS Appl. Mater. Interfaces, 2015, 7, 10132.

2 K. Haupt, Nature Biotechnol., 2002, 20, 884; G. Vlatais, L. I. Andersson, R. Muller and K. Mosbach, Nature, 1993, 361, 645; C.S. Mahon and D.A. Fulton, Nat. Chem., 2014, 6, 665; A. V. Linares, A. Falcimaigne-Cordin, L. A. Gheber and K. Haupt, Small, 2011, 7, 2318; N. Griffete, H. Li, A. Lamouri, C. Redeuilh, K. Chen, C. Z. Dong, S. Nowak, S. Ammar and C. Mangeney, J. Mater. Chem., 2012, 22, 1807; N. Griffete, H. Frederich, A. Maitre, S. Ravaine, M.M. Chehimi and C. Mangeney, Langmuir, 2012, 28, 1005; N. Griffete, H. Frederich, A. Maitre, C. Schwob, S. Ravaine, B. Carbonnier, M.M. Chehimi and C. Mangeney, J. Colloid Interface Sci. 2011, 364, 18.

3 Y. Liu, S. Fang, J. Zhaia and M. Zhao, Nanoscale, 2015, 7, 7162; R. Schirhagl, Anal. Chem., 2014, 86, 250.

4 D. Cunliffe A. Kirby and C. Alexander, Adv. Drug Deliv. Rev., 2005, 57, 1836; G. Cirillo, O. I. Parisi, M. Curcio, F. Puoci, F. lemma, U. G. Spizzirri and N. Picci, J. Pharm. Pharmacol., 2010, 62, 577.

5 M. Zhang, X. Zhang, X. He, L. Chen and Y. Zhang, Nanoscale, 2012, 4, 3141; J. L. Urraca, A. J. Hall, M. C. MorenoBondi and B. Sellergren, Angew. Chem, 2006, 118, 5282.

6 S. Wang, J. Ye, Z. Bie and Z. Liu, Chem. Sci., 2014, 5, 1135; J. Ye, Y. Chen and Z. Liu, Angew. Chem. Int. Ed., 2014, 53, 10386; Y. Hoshino, H. Koide, T. Urakami, H. Kanazawa, T. Kodama, N. Oku and K. J. Shea, J. Am. Chem. Soc., 2010, 132, 6644; W. Wu, J. Shen, Y. Li, H. Zhu, P. Banerjee and S. Zhou, Biomaterials, 2012, 33, 7115.

7 J.P. Fortin, M.S. Martina, F. Gazeau, C. Ménager, C. Wilhelm, J.C. Bacri, S. Lesieur and O. Clément, Radiology, 2007, 239, 415; M.S. Martina, J.P. Fortin, C. Ménager, O. Clément, G. Barratt, C. Grabielle-Madelmont, F. Gazeau, V. Cabuil and S. Lesieur, J. Am. Chem. Soc., 2005, 127, 10676; J. P. Williams, P. Southern, A. Lissina, H. C . Christian, A. K. Sewell, R Phillips, Q. Pankhurst and J. Frater, Int. J. Nanomed., 2013, 8, 2543; L. Jae-Hyun, L. Kyuri, M.Seung Ho, L. Yuhan, P. Tae Gwan and C. Jinwoo, Angew. Chem. Int. Ed., 2009, 48, 4174.

8 J. P. Fortin, C. Wilhelm, J. Servais, C. Ménager, J. C. Bacri and F. Gazeau, J. Am. Chem. Soc., 2007, 129, 2628; M. Yu, Y. Jeong, J. Park, S. Park, J. Kim, J. Min, K. Kim and S. Jon, Angew. Chem. Int. Ed., 2008, 47, 5362; T. Neuberger, B. Schopf, H. Hofmann, M. Hofmann and B. Von Rechenberg, J. Magn. Magn. Mater., 2005, 293, 483; J. Xie, K. Chen, H. Lee, C. Xu, A. R. Hsu, S. Peng, X. Chen and S. Sun, J. Am. Chem. Soc., 2008, 130, 7542

9 S. Louguet, B. Rousseau, R. Epherre, N. Guidolin, G. Goglio, S Mornet, E. Duguet and S. Lecommandoux, C. Schatz, Polym. Chem., 2012, 3, 1408

10 G. Béalle, L. Lartigue, C. Wilhelm, J. Ravaux, F. Gazeau, R. Podor, D. Carrière and C. Ménager, Phys. Chem. Chem. Phys.
2014, 16, 4077; T. Ren, Q. Liu, H. Lu, H. Liu, X. Zhang and J. Du, J. Mater. Chem. 2012, 22, 12329.

11 A. Baeza, E. Guisasola, E. Ruiz-Hernández and M.Vallet-Regí, Chem. Mater, 2012, 24, 517.

12 S. H. Hu, B. J. Liao, C. S. Chiang, P. J. Chen, I. W. Chen and S. Y. Chen, Adv. Mater., 2012, 24, 3627; S. H. Hu, S. Y. Chen and X. Gao, ACS Nano, 2012, 6, 2558; C. Sanson, O. Diou, J. Thévenot, E. Ibarboure, A. Soum, A. Brulet, S. Miraux, E. Thiaudière, S. Tan, A. Brisson, V. Dupuis, O. Sandre and S. Lecommandoux, ACS Nano, 2011, 5, 1122.

13 H. Nobuto, T. Sugita, T. Kubo, S. Shimose, Y. Yasunaga, T. Murakami and M. Ochi, Int. J. Cancer, 2004, 109, 627; VP. Torchilin, Nature Rev., 2005, 4, 145; E. Amstad, J. Kohlbrecher, E. Müller, T. Schweizer, M. Textor and E. Reimhult, Nano Lett., 2011, 11, 1664.

14 J. E Wong, AK Gaharwar, DM Schulte, D Bahadur and W Richtering, J.Magn.Magn. Mater., 2007, 311, 219.

15 C. S. S. R. Kumar and F. Mohammad, Adv. Drug Deliv. Rev., 2011, 63, 789; S. L. McGill, C. L. Cuylear, N. L. Adolphi, M. Osinski and H. D. C. Smyth, IEEE Trans. Nanobiosci., 2009, 8, 33.

16 T. T. T. N'Guyen, H. T. T. Duong, J. Basuki, V. Montembault, S. Pascual, C. Guibert, J. Fresnais, C. Boyer, M. R. Whittaker, T. P. Davis and L. Fontaine, Angew. Chem. Int. Ed., 2013, 52, 14152.

17 J. H. Lee, K. J. Chen, S. H. Noh, M. A. Garcia, H. Wang, W. Y. Lin, H. Jeong, B. J. Kong, D. B. Stout, J. Cheon and H. R. Tseng, Angew. Chem., 2013, 125, 4480.

18 K.H. Bae, M. Park, M.J. Do, N. Lee, J.H. Ryu, G.W. Kim, C.Kim, T.G.Park and T. Hyeon, ACS Nano, 2012, 6, 5266; S.A. Stanley, J.E. Gagner, S. Damanpour, M. Yoshida, J.S. Dordick and J.M. Friedman, Science, 2012, 336, 604; H. Huang,S. Delikanli, H. Zeng, D.M. Ferkey and A. Pralle, Nature Nanotechnology, 2010, 5, 602; M. Domenech, I. MarreroBerrios, M. Torres-Lugo and C. Rinaldi, ACS Nano, 2013, 7, 5091; D. Fourmy, J. Carrey and V. Gigoux, Nanomedicine, 2015, 10, 893.

19 B. Liu, M. Han, G. Guan, S.Wang, R. Liu and Z. Zhang, J. Phys. Chem. C, 2011, 115, 17320.

20 S. Lefebure, E. Dubois, V. Cabuil, S. Neveu and R. Massart, J. Mat. Res., 1998, 13, 2975.

21 A. Ellwanger, C. Berggren, S. Bayoudh, C. Crecenzi, L. Karlsson, P. K. Owens, K. Ensing, P. Cormack, D. Sherrington and B. Sellergren, Analyst, 2001, 126, 784; M. Ahmadi, T. Madrakian and A. Afkhami, New J. Chem., 2015, 39, 163. 